\title{
Cytogenetics of Four Species of Genus Berberis L. (Berberidaceae Juss.) from the Western Himalayas
}

\author{
Syed M. Jeelani ${ }^{1 *}$, Sanjeev Kumar ${ }^{2}$, Savita Rani ${ }^{3}$, \\ Santosh Kumari ${ }^{2}$, and Raghbir C. Gupta ${ }^{2}$ \\ ${ }^{1}$ Division of Floriculture, Medicinal and Aromatic Plants (FMAP), Shere-e- Kashmir University \\ of Agricultural Sciences and Technology of Kashmir, (SKUAST-K), Shalimar, Srinagar \\ (Jammu \& Kashmir) 190025 \\ ${ }^{2}$ Department of Botany, Punjabi University, Patiala, Punjab 147 002, India \\ ${ }^{3}$ Department of Agricultural Biotechnology CSK HPKV Palampur-176062
}

Received August 8, 2013; accepted January 12, 2014

\begin{abstract}
Summary The genus Berberis belongs to the family Berberidaceae and includes mostly wild, important medicinal plants. Meiotic studies have been carried out for analyzing the genetic diversity in 11 populations covering four species from different selected parts of the Western Himalayas, such as Kashmir (Jammu and Kashmir) and the districts of Kangra and Sirmaur (Himachal Pradesh). The species being cytologically worked out for the first time worldwide include B. ceratophylla $(2 n=28)$. Similarly, B. vulgaris $(2 n=28)$, although worked out earlier from other countries, is being reported cytologically for the first time from India. The meiotic course in most of these populations has been observed to be normal except for a single population each of $B$. asiatica, B. ceratophylla and $B$. vulgaris marked with abnormal meiosis. Out of these three species, two ( $B$. asiatica and B. vulgaris) are marked with cytomixis. These meiotic abnormalities lead to the production of heterogenous-sized fertile pollen grains and reduced pollen fertility.
\end{abstract}

Key words Berberis, Chromosome number, Meiotic abnormality, Western Himalayas.

Berberis is popularly known as barberry and is the largest genus of the family containing about 500 species native to the temperate and subtropical regions of Europe, Asia, Africa, and North and South America (Ahrendt 1961). It includes 55 species from India (Rao et al. 1998). Taxonomically, Berberis is considered a very complex genus with variable characters in its species. The genus is characterized by deciduous or evergreen shrubs with thorny yellow stems, simple leaves and sepals usually in two series or whorls.

Many species of Berberis are known for their ethnobotanical properties. For example, the root extracts of B. asiatica, B. lyceum and B. chitria are used as an antidiarrhoeal, laxative, antiseptic, intestinal astringent, cough medicine and a blood purifier (Khare 2007, Qureshi et al. 2007, Gangwar et al. 2010). Other species of Berberis, such as B. holstii and B. vulgaris, are medicinally important due to the presence of alkaloids with different pharmacological properties (MaliwichiNyirenda et al. 2011).

Several cytological studies have been made in the genus from different parts of the world by different researchers (Pogan et al. 1980, Sheng et al. 2010). However, most of these studies are concentrated on the evaluation of chromosome numbers with only a few studies carried out for the study of meiotic behavior (Yan-Jun et al. 2006, Rounsaville and Ranney 2010) and a single cytomorphological study (Heidary et al. 2009). Some of the cytological contributions from India

*Corresponding author, e-mail: sandrabi555@gmail.com

DOI: $10.1508 /$ cytologia.79.111 
include those by Mehra and Sareen (1969), Singhal et al. (1980), Gill et al. (1984) and Sandhu and Mann (1988), but they all represent the same chromosome number evaluation. In this regard, the present study is the first attempt to look for genetic diversity in the different species of the genus from the Western Himalayas to segregate the variants for further exploitation along with adding information to the chromosomal database of Indian plants. Furthermore, we study the effects of different meiotic abnormalities on pollen fertility and pollen size in the abnormal populations/ species.

\section{Materials and methods}

During the present investigations, materials for cytomorphological studies were collected from different populations of the wild plants growing in different climatic zones in different seasons. For meiotic studies, young flower buds of an appropriate size were collected during the peak flowering period. These buds were fixed in Carnoy's fixative (six parts ethyl alcohol, three parts chloroform and one part glacial acetic acid) for $24-48 \mathrm{~h}$. Then, the materials were transferred to $75 \%$ ethyl alcohol and stored in a refrigerator at about $4-10^{\circ} \mathrm{C}$. For chromosomal preparations, smears of the young anthers were made in 1\% acetocarmine following the technique of Belling (1921). Pollen fertility was determined through the stainability of pollen grains in $50 \%$ glyceroacetocarmine (Marks 1954). Only well-filled pollen grains and those with well-stained nuclei were taken as apparently fertile and viable. The pollen grain size was measured with an ocular micrometer. Photomicrographs of PMCs for chromosomal counts, meiotic irregularities, sporads and pollen grains were made from the freshly prepared slides using a Nikon Eclipse 80i microscope (X330, X1340 and X3400). Voucher specimens were deposited in the Herbarium, Department of Botany, Punjabi University, Patiala (PUN).

\section{Results}

Detailed population-based meiotic studies have been carried out on 11 populations covering four species belonging to the genus Berberis of the family Berberidaceae from different localities with an altitudinal range of 1,800-3,000 $\mathrm{m}$ in the districts of Kangra and Sirmaur of Himachal Pradesh and 1,800-2,300 $\mathrm{m}$ in Kashmir. The data regarding locality, altitude, voucher specimen number (PUN), and present and previous chromosome number reports of the presently studied species have been presented in Table 1 .

Based on $x=14$, all the 11 populations of the four species, namely B. asiatica, B. ceratophylla, $B$. chitria and $B$. vulgaris, invariably depict the same diploid chromosome number $(2 n=28)$ (Figs. $1-4)$. The present chromosome number, $2 n=28$, for $B$. ceratophylla is the first cytological report for the species in the world, and for B. vulgaris $(2 n=28)$, it is the first report from India.

Meiotic abnormalities have been recorded in some populations of $B$. asiatica and $B$. ceratophylla and all the populations of $B$. vulgaris except $B$. chitria, which showed a normal course of meiosis. In such populations, abnormalities in the form of cytomixis, chromatin stickiness, unoriented bivalents, bridges and laggards as well as multipolarity have been observed at different stages of meiosis (Figs. 5-10; Table 2). Cytomixis in these species results in the production of hyper- and hypo-ploid PMCs (Figs. 5, 6; Table 2), except in B. ceratophylla where no cytomixis is observed. It is seen that late or non-disjuncting bivalent bridges and chromosomal laggards are most common. Chromatin stickiness involving few bivalents or the whole complement is seen from prophase-I to metaphase-I. This results in abnormal microsporogenesis leading to the formation of diads, triads and polyads (Figs. 10, 11, 14). Further, micronuclei have also been observed in most of these species (Figs. 11-14; Table 3). These meiotic abnormalities along with abnormal microsporogenesis lead to the formation of heterogeneous-sized fertile pollen grains and reduced 
Table 1. Data showing locality, altitude with accession number (PUN) and $2 n$ chromosome number (present and previous reports) of the presently studied species of genus Berberis from the Western Himalayas.

\begin{tabular}{|c|c|c|c|c|}
\hline \multirow{2}{*}{ S. No. } & \multirow{2}{*}{ Taxa } & \multirow{2}{*}{$\begin{array}{l}\text { Locality/Altitude (m)/ } \\
\text { Accession number }\end{array}$} & \multicolumn{2}{|c|}{ Chromosome number } \\
\hline & & & Present report & Previous reports* \\
\hline \multirow[t]{4}{*}{1} & \multirow[t]{4}{*}{$\begin{array}{l}\text { Berberis asiatica Roxb. } \\
(=B \text {. lycium Royle) }\end{array}$} & $\begin{array}{l}\text { Bara-gran, District/ } \\
\text { Kangra (H.P); 3,000/ } \\
55133\end{array}$ & $2 n=28$ & \multirow{4}{*}{$\begin{array}{l}2 n=28 \text { Mehra } 1976, \\
\text { Sandhu \& Mann 1988, } \\
\text { Malla et al. } 1975, \text { Gill } \\
\text { et al. } 1984, \text { Singhal and } \\
\text { Gill } 1984 .\end{array}$} \\
\hline & & $\begin{array}{l}\text { Nauradhar, District/ } \\
\text { Sirmaur (H.P.); 1,800/ } \\
57334\end{array}$ & $2 n=28$ & \\
\hline & & $\begin{array}{l}\text { Batnoor-Tral, District/ } \\
\text { Pulwama (J\&K); 2,200/ } \\
57291\end{array}$ & $2 n=28$ & \\
\hline & & $\begin{array}{l}\text { Tangmarg, District/ } \\
\text { Baramulla (J\&K); 2,300/ } \\
57258\end{array}$ & $2 n=28$ & \\
\hline \multirow[t]{2}{*}{2} & \multirow[t]{2}{*}{ B. ceratophylla G. Don } & $\begin{array}{l}\text { Chotta-bhangal/ } \\
\text { District Kangra (H.P); 2,300/ } \\
55080\end{array}$ & $2 n=28$ & \multirow[t]{2}{*}{ No Reports } \\
\hline & & $\begin{array}{l}\text { Triund, District/ } \\
\text { Kangra (H.P); 3,000/ } \\
55899\end{array}$ & $2 n=28$ & \\
\hline \multirow[t]{2}{*}{3} & \multirow[t]{2}{*}{ B. chitria Lindl. } & $\begin{array}{l}\text { Shillai, District/ } \\
\text { Sirmaur (H.P.); 2,000/ } \\
55991\end{array}$ & $2 n=28$ & \multirow[t]{2}{*}{$\begin{array}{l}2 n=28 \text { Singhal et al. } \\
1980 .\end{array}$} \\
\hline & & $\begin{array}{l}\text { Chapdhar, District/ } \\
\text { Sirmaur (H.P.); 2,400/ } \\
56026\end{array}$ & $2 n=28$ & \\
\hline \multirow[t]{3}{*}{4.} & \multirow[t]{3}{*}{ B. vulgaris $\mathrm{L}$. } & $\begin{array}{l}\text { Boh, District/ } \\
\text { Kangra (H.P); 1,900/ } \\
55129\end{array}$ & $2 n=28$ & \multirow{3}{*}{$\begin{array}{l}\text { 2n=28 Langlet 1928, } \\
\text { Tischler 1928, Dermen } \\
\text { 1931, Giffen 1936, } \\
\text { Delay 1947, Magulaev } \\
\text { 1984, Verlaque et al. } \\
\text { 1987, Pogan et al. } \\
\text { 1980, Měsíček 1992. }\end{array}$} \\
\hline & & $\begin{array}{l}\text { Dachigam, District/ } \\
\text { Srinagar (J\&K); 1,800/ } \\
52474\end{array}$ & $2 \mathrm{n}=28$ & \\
\hline & & $\begin{array}{l}\text { Tral, District/ } \\
\text { Pulwama (J\&K); 1,900/ } \\
56221\end{array}$ & $2 n=28$ & \\
\hline
\end{tabular}

* Previous chromosome number reports are based on literature [Chromosomal Atlases by Fedorov (1969), and Kumar and Subramanian Vol. I (1986)]; Index to Plant Chromosome Number Reports from 1968 onwards; various journals, proceeding volumes and the Internet.

pollen fertility (Figs. 15, 16; Table 2).

Three populations $(57334,57291$ and 57258) of $B$. asiatica, one population (55899) of $B$. ceratophylla and all two populations (55991 and 56026) of $B$. chitria have been observed to exhibit normal meiotic course, and their pollen fertility was nearly $100 \%$.

\section{Discussion}

A perusal of the cytological collective literature shows that 110 species/110 cytotypes of the genus Berberis, including 15 species from India, have been cytologically examined and found to have $2 n=28(90.90 \%), 2 n=42(1.82 \%)$ or $2 n=56(7.27 \%)$ (cf. Fedorov 1969, Kumar and Subramanian 1986, Index to Plant Chromosome Numbers, web, etc.). However, the genus is monobasic, i.e., $x=14$, as suggested earlier by Bottini et al. (1999). Polyploidy is noted to be $8.18 \%$ 

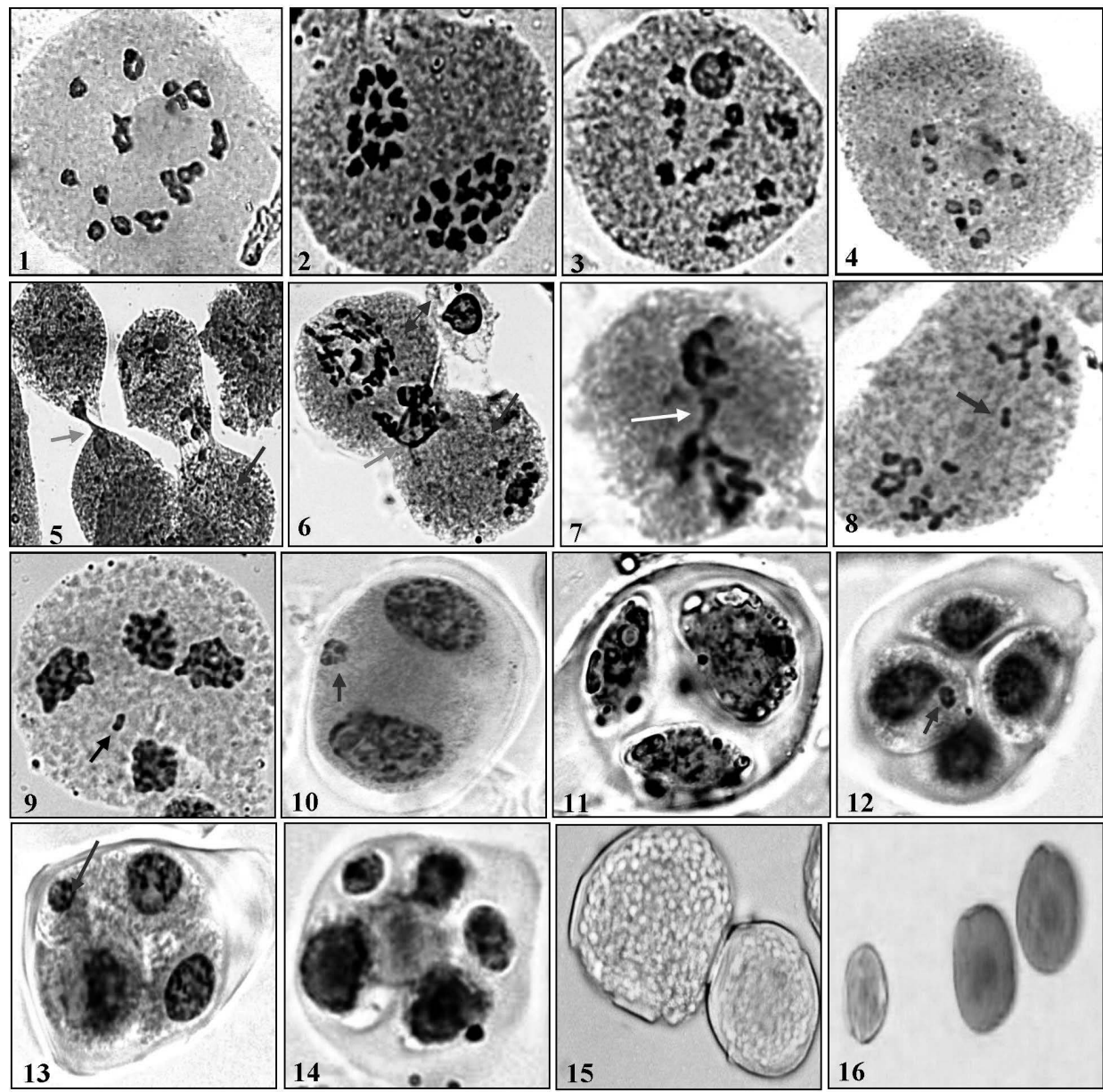

Figs. 1-16. 1. B. asiatica $(2 n=28)$ Diakinesis. 2. B. ceratophylla $(2 n=28)$ Anaphase-I. 3. B. chitria $(2 n=28)$ Diakinesis. 4. B. vulgaris $(2 n=28)$ Metaphase-I. 5,6. PMCs (Pollen Mother Cells) showing chromatin transfer at Anaphase-I with hyperploid (double headed arrow) and hypoploid cells (single headed arrow). 7. PMC shows bridge (arrowed) at Anaphase-I. 8. PMC showing laggards (arrowed) at Anaphase-I. 9. PMC showing laggard (arrowed) at Anaphase-I. 10. Diad with micronucleus (arrowed). 11. Triad. 12,13. Tetrad with micronucleus (arrowed). 14. Polyad. 15. Heterogeneous-sized fertile pollen grains. 16. Fertile and sterile pollen grains. Scale $10 \mu \mathrm{m}$.

compared to $6 \%$ as previously reported by Hong (1990) for species with only diploids known from India.

Cytomixis, chromosomal stickiness, unoriented bivalents, laggards and bridges among the presently studied species at the population level indicate the existence of intraspecific genetic diversity. Such genetic differences have been seen earlier in different plant species (BaptistaGiacomelli et al. 2000, Sheidai et al. 2008, Jeelani et al. 2012, Rani et al. 2012, 2013, Kumar et al. 2013). Cytomixis and chromatin stickiness are considered to result from genetic factors (Bellucci et al. 2003, Ghaffari 2006, Fadaei et al. 2010), environmental factors (Nirmala and Rao 1996) or genomic-environmental interactions (Baptista-Giacomelli et al. 2000). These factors all seem equally applicable to the presently investigated taxa. Cytomixis or the occurrence of multipolar cells and meiotic irregularities in anaphase segregation of chromosomes may be the possible mechanisms for the formation of large-sized pollen grains and low pollen fertility in these meiotically abnormal populations as has been reported earlier in several angiospermic plants 


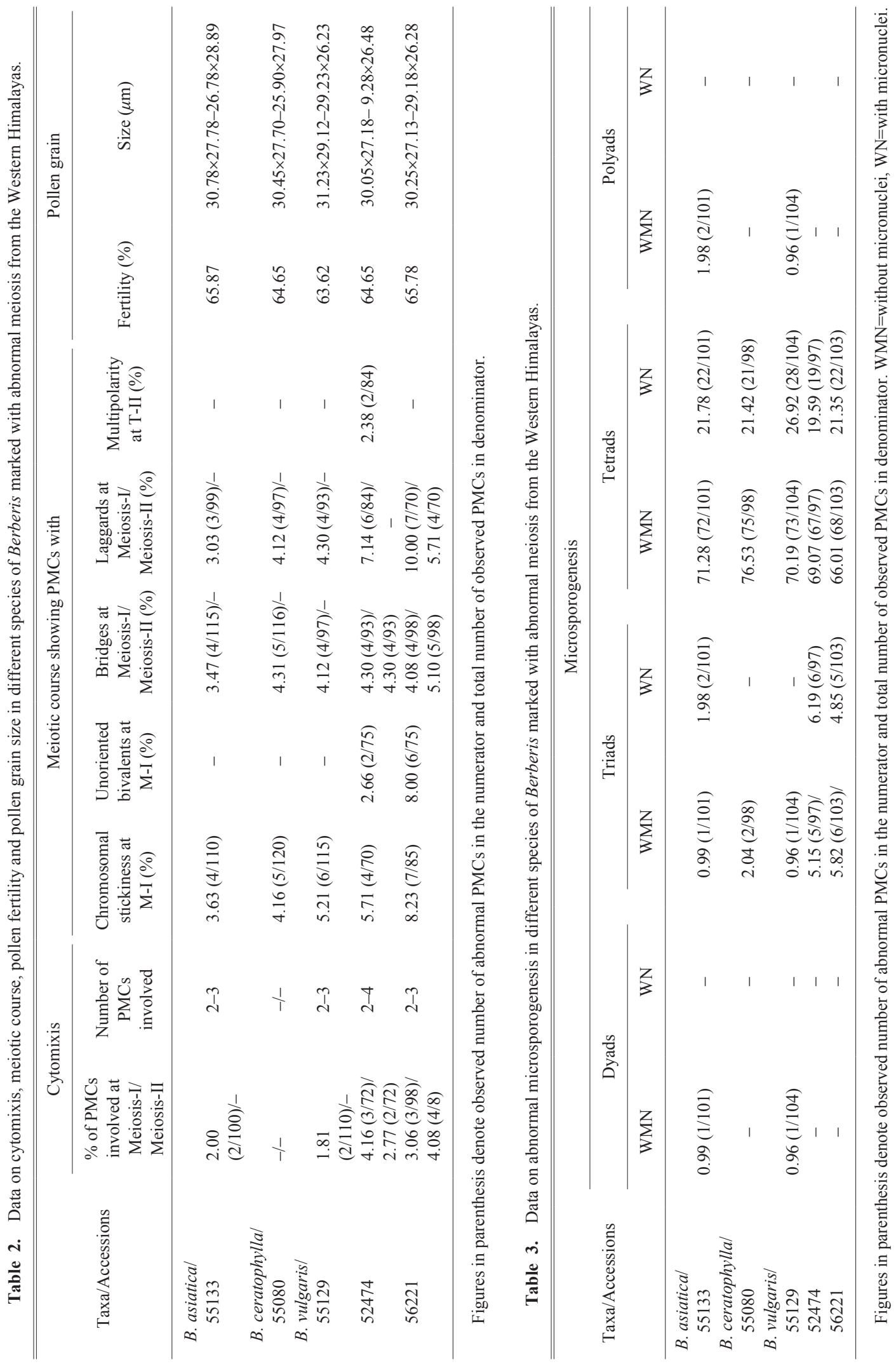


(Sheidai et al. 2008, Jeelani et al. 2011, 2012, Rani et al. 2012, 2013, Kumar et al. 2013). The production of hypo- and hyperploid PMCs due to cytomixis (Falistocco et al. 1995, Sheidai and Bagheri-Shabestarei 2007, Fadaei et al. 2010, Jeelani et al. 2012) accompanied by other meiotic abnormalities lead to anomalous microsporogenesis, resulting in the formation of variable-sized pollen grains, possibly with an aneuploid condition and low pollen fertility (Villeux 1985, Nirmala and Rao 1996, Sheidai and Fadael 2005, Sheidai et al. 2003, Jeelani et al. 2012). The formation of large-sized pollen grains as seen at present is in accordance with previous information about the possibility of such pollen grains resulting from unreduced $2 n$ pollen grains as has been observed in several angiosperms by Vorsa and Bingham (1979), Bertagnolle and Thomson (1995), Sheidai et al. (2008), Fadaei et al. (2010) and Jeelani et al. (2011).

The occurrence of limited variation of chromosome numbers but diversity in meiotic behavior at the intraspecific level of the presently studied species demands the need for extensive cytological exploration on a population basis in the genus Berberis from different geographical areas.

\section{Acknowledgements}

The authors are grateful to the University Grants Commission, New Delhi, for the award of Dr. D.S. Kothari Post-Doctoral Fellowship to Dr. Syed Mudassir Jeelani and Rajiv Gandhi National Fellowship to Dr. Sanjeev Kumar. We are also obliged to Department of Science and Technology, New Delhi, for the honour of Young Scientist Fellowship to Dr. Savita Rani. Moreover, thanks are due to the Head, Department of Botany, Punjabi University, Patiala, for providing the necessary laboratory facilities and Director of Botanical Survey of India, DehraDun, for the identification of the plant species.

\section{References}

Ahrendt, L. W. A. 1961. Berberis and Mahonia, a taxonomic revision. Bot. J. Linn. Soc. 57: 1-410.

Baptista-Giacomelli, F. R., Palgliarini, M. S., and Almeida, J. L. 2000. Meiotic behavior in several Brazilian oat cultivars (Avena sativa L.). Cytologia 65: 371-378.

Belling, J. 1921. On counting chromosomes in pollen mother cells. Am. Nat. 55: 573-574.

Bellucci, M., Roscini, C., and Mariani, A. 2003. Cytomixis in pollen mother cells of Medicago sativa L. J. Hered. 94: 512516.

Bertagnolle, F., and Thompson, J. D. 1995. Gametes with the somatic chromosome number, mechanisms of their formation and role in the evolution of autopolyploid plants. New Phytol. 129: 1-22.

Bottini, M. C. J., Greizerstein, E. J., and Poggio, L. 1999. Ploidy levels and their relationships with the rainfall in several populations of Patagonian species of Berberis L. Caryologia 52: 75-80.

Fadaei, F., Sheidai, M., and Asadi, M. 2010. Cytological study the genus Arenaria L. (Caryophyllaceae). Caryologia 63: $149-156$.

Falistocco, E., Tosti, N., and Falcinelli, M. 1995. Cytomixis in pollen mother cells of diploid Dactylis, one of the origins of $2 n$ gametes. J. Hered. 86: 448-453.

Fedorov, An. A. (ed.). 1969. Chromosome Numbers of Flowering Plants. Academy of Sciences of the USSR. Komarov Botanical Institute, Leningard.

Gangwar, K. K., Deepali, G. R. S., and Gangwar, R. S. 2010. Ethnomedicinal plant diversity in Kumaun Himalaya of Uttarakhand, India. Nat. Sci. 5: 66-78.

Ghaffari, S. M. 2006. Occurrence of diploid and polyploid microspores in Sorghum bicolor (Poaceae) is the result of cytomixis. Afr. J. Biotechnol. 5: 1450-1453.

Gill, B. S., Bir, S. S., Sidhu, M. S., and Singhal, V. K. 1984. In: IOPB chromosome number reports LXXXIV. Taxon 33: 538.

Heidary S., Marashi H., Farsi M., \& Kakhki A. M. 2009. Assessment of genetic structure and variation of native Berberis populations of Khorasan provinces (Iran) using AFLP markers versus morphological markers. Iranian J. Biotec. 7: 34-45.

Hong, D. Y. 1990. Plant Cytotaxonomy. Science Press, Beijing. pp. 300-304.

Jeelani, S. M., Kumari, S., and Gupta, R. C. 2012. Meiotic studies in some selected angiosperms from the Kashmir 
Himalayas. J. Syst. Evol. 50: 244-257.

Jeelani, S. M., Rani, S., Kumar, S., Kumari, S., and Gupta, R. C. 2011. Meiotic studies in some members of Caryophyllaceae Juss. from the Western Himalayas. Acta Biol. Crac. Ser. Bot. 53: 86-95.

Khare, C. P. (ed.) 2007. Indian Medicinal Plants: An Illustrated Dictionary. Springer, New York.

Kumar, S., Jeelani, S. M., Rani, S., Gupta, R. C., and Kumari, S. 2013. Cytology of five species of subfamily Papaveroideae from the Western Himalayas. Protoplasma 250: 307-316.

Kumar, V., and Subramanian, B. 1986. Chromosome Atlas of Flowering Plants of the Indian Sub-continent. Vol. I. Dicotyledons. Botanical Survey of India, Calcutta.

Maliwichi-Nyirenda, C. P., Maliwichi, L. L., and Franco, M. 2011. Medicinal uses of Berberis holstii Engl. (Berberidaceae) in Malawi, the only African endemic barberry. J. Med. Plant Res. 5: 1367-1373.

Marks, G. E. 1954. An acetocarmine glycerol jelly for use in pollen fertility counts. Stain Technol. 29: 277.

Mehra, P. N., and Sareen, T. S. 1969. In: IOPB chromosome Number Reports XXII. Taxon 18: 433-442.

Nirmala, A., and Rao, P. N. 1996. Genesis of chromosomal numerical mosaicism in higher plants. Nucleus 39: 151-175.

Pogan, E., Sawicka, H., and Jankun, A. 1980. Further studies in chromosome numbers of Polish Angiosperms, Part 22. Acta Biol. Crac. Ser. Bot. 31: 1-7.

Qureshi, R. A., Ghufran, M. A., Gilani, S. A., Sultana, K., and Ashraf, M. 2007. Ethnobotanical studies of selected medicinal Plants of sudhan gali and ganga chotti hills, District bagh. Azad Kashmir. Pak. J. Bot. 39: 2275-2283.

Rani, S., Kumar, S., Jeelani, S. M., Kumari, S., and Gupta, R. C. 2012. Additions to the cytologically investigated species of Potentilla L. (Rosaceae) from India. Plant Syst. Evol. 298: 485-497.

Rani, S., Kumar, S., Jeelani, S. M., Kumari, S., and Gupta, R. C. 2013. Impaired male meiosis, morphology and distribution pattern of diploid and tetraploid cytotypes of Bupleurum lanceolatum Wall. (Apiaceae) from the Western Himalayas. Plant Syst. Evol. 299: 1801-1807.

Rao, R. R., Husain, T., Dutt, B., and Atri, G. 1998. Revision of the family Berberidaceae of India-I. Rheedea 8: 1-66.

Rounsaville, T. J., and Ranney, T. G. 2010. Ploidy levels and genome sizes of Berberis L. and Mahonia Nutt. species, hybrids, and cultivars. HortScience 45: 1029-1033.

Sandhu, P. S., and Mann, S. K. 1988. SOCGI plant chromosome number reports VII. J. Cytol. Genet. 23: $179-182$.

Sheidai, M., and Bagheri-Shabestarei, E. S. 2007. Cytotaxonomy of some Festuca species and populations in Iran. Acta Bot. Croat. 66: 143-151.

Sheidai, M., and Fadael, F. 2005. Cytogenetic studies in some Bromus L. species sec. Genea. J. Genet. 84: $189-194$.

Sheidai, M., Koobaz, P., and Zehzad, B. 2003. Meiotic studies of some Avena species and populations in Iran. J. Sci. Isl. Rep. Iran 14: 121-131.

Sheidai, M., Nikoo, M., and Gholipour, A. 2008. Cytogenetic variability and new chromosome number reports in Silene L. species (Sect. Lasiostemones, Caryophyllaceae). Acta Biol. Szeged. 52: 313-319.

Sheng, M. Y., Wang. L. J., and Tian, X. J. 2010. Karyomorphology of eighteen species of genus Epimedium (Berberidaceae) and its phylogenetic implications. Genet. Resour. Crop Evol. 57: 1165-1176.

Singhal, V. K., Gill, B. S., and Bir, S. S. 1980. In: Chromosome number reports LXVII. Taxon 29: 347-363.

Villeux, R. 1985. Diploid and polyploidy gametes in Crop Plants: Mechanisms of formation and utilization in plant breeding. In: Janick, J. (ed.). Plant Breed Rev 3, AVI Publishing Co., Westport, Connecticut. p. 442.

Vorsa, N., and Bingham, E. T. 1979. Cytology of $2 n$ pollen formation in diploid alfa, Medicago sativa. Can. J. Genet. Cytol. 21: 525-530.

Yan-Jun, Z., Meng, A. P., Li, J. Q., Dang, H. S., and Li, X. W. 2006. Observation on meiotic behavior in three Mahonia species, with special reference to the intergeneric relationship of Mahonia and Berberis. Caryologia 59: 305-311. 